\title{
The effects of pinealectomy and superior cervical ganglionectomy on the testis of the vole, Microtus agrestis
}

\author{
H. M. Charlton, C. Anne Grocock and Anna Ostberg* \\ Department of Human Anatomy, University of Oxford, South Parks Road, \\ Oxford OXI $3 Q X, U . K$.
}

The pineal gland has been implicated as a part of the controlling mechanism for the hypothalamohypophysial-gonadal axis in several species. Removal of the pineal in ferrets (Herbert, 1971), hamsters (Hoffman \& Reiter, 1965; Reiter, 1973) and bramblings (Haase \& Follett, 1974) prevents the inhibitory effects of short photoperiods on the testes. Similar results have been obtained in the hamster by removing the superior cervical ganglia (Reiter \& Hester, 1966) which innervate the pineal by postganglionic sympathetic fibres (Kappers, 1965). Clarke \& Farrar (1975) have shown that chemical sympathectomy, using 6-hydroxy-dopamine, affects gonadal activity in voles.

To test whether similar effects could be obtained in voles, two types of experiments were performed; in the first, the effect of pinealectomy on testicular activity was investigated, and in the second similar observations were made on animals in which both superior cervical ganglia had been removed.

Male voles were taken from the breeding colony in the Department of Human Anatomy either as weanlings, 2-4 weeks old, or as sexually mature animals, 2-3 months old. All animals had previously been kept in a long photoperiod (16L:8D). In Exp. I weanling male voles were either pinealectomized or underwent a control operation which entailed the drilling of a burr hole above the region of the pineal and the disruption of the superior sagittal and transverse sinuses. The animals were then subjected to short photoperiods (6L:18D) for 4 weeks (Group A) or 8 weeks (Group B). This photoperiod is known to inhibit gonadal function in voles (Clarke \& Kennedy, 1967).

In Exp. II weanling (Groups $C$ and D) and mature (Groups $E$ and F) male voles were either bilaterally ganglionectomized or sham-operated. As in Exp. I animals were subjected to short photoperiods for 4 (Groups C and E) or 8 (Groups D and F) weeks.

At the end of the experiments the animals were killed, and testes and seminal vesicles were removed, fixed in Bouin's fluid and weighed later. Paraffin-wax sections of testes were stained with haematoxylin and eosin. Estimates of the development of spermatogenesis were made and 10 tubule diameters were measured at random for each testis; the mean for each animal was then used to calculate an overall mean for each treatment.

\section{Weanling animals}

After 4 and 8 weeks treatment, pinealectomized and ganglionectomized animals had heavier testes than their corresponding controls (Table 1). The testes of Group B animals were larger than those of Group A voles, reflecting the fact that after 4 weeks treatment the animals had not yet reached full testicular development. Similar results were found with the seminal vesicle weights. Seminiferous tubule diameters were significantly larger in weanling males which had been ganglionectomized or pinealectomized than in the respective controls. Spermatozoa were present in large numbers in the treated animals but in most of the control voles spermatogenic development had proceeded only to meiotic prophase.

\section{Mature animals}

As shown in Table 1, differences were found for seminal vesicle weights of all groups and for testicular weights of ganglionectomized animals exposed for 8 weeks.

\footnotetext{
* Present address: Department of Neurobiology, National Institute for Medical Research, Mill Hill, London, U.K.
} 
Table 1. Mean ( \pm S.E.M) organ weights and seminiferous tubule diameter in weanling (Groups IA, IB, IIC and IID) and mature (Groups IIE and IIF) voles subjected to pinealectomy or bilateral ganglionectomy and exposed to short photoperiods for different times

\begin{tabular}{|c|c|c|c|c|c|}
\hline Exp. & $\begin{array}{l}\text { Treatment and } \\
\text { exposure time to } \\
6 \mathrm{~L}: 18 \mathrm{D}\end{array}$ & $\begin{array}{l}\text { No. of } \\
\text { voles }\end{array}$ & Wt of testes (mg) & $\begin{array}{l}\text { Seminal vesicle } \\
\text { wt (mg) }\end{array}$ & $\begin{array}{c}\text { Seminiferous } \\
\text { tubule diameter } \\
(\mu \mathrm{m})\end{array}$ \\
\hline \multirow[t]{2}{*}{ IA } & $\begin{array}{l}\text { Pinealectomized, } \\
4 \text { weeks }\end{array}$ & 10 & $336 \cdot 4 \pm 25 \cdot 0^{* * *}$ & $33 \cdot 4 \pm 4 \cdot 6^{* * *}$ & $143 \cdot 4 \pm 4 \cdot 2^{* * *}$ \\
\hline & $\begin{array}{l}\text { Control (sham-op.), } \\
4 \text { weeks }\end{array}$ & 5 & $105 \cdot 6 \pm 29 \cdot 0$ & $4 \cdot 2 \pm 1 \cdot 7$ & $82 \cdot 2 \pm 10 \cdot 3$ \\
\hline \multirow[t]{2}{*}{ IB } & $\begin{array}{l}\text { Pinealectomized, } \\
8 \text { weeks }\end{array}$ & 8 & $480 \cdot 2 \pm 55 \cdot 4^{* * *}$ & $68 \cdot 6 \pm 10 \cdot 0^{* *}$ & $188 \cdot 25 \pm 4 \cdot 7^{* * *}$ \\
\hline & $\begin{array}{l}\text { Control (sham-op.), } \\
8 \text { weeks }\end{array}$ & 6 & $123 \cdot 7 \pm 36 \cdot 0$ & $14 \cdot 5 \pm 6 \cdot 0$ & $88.7 \pm 7.9$ \\
\hline \multirow[t]{2}{*}{ IIC } & $\begin{array}{l}\text { Ganglionectomized, } \\
4 \text { weeks }\end{array}$ & 10 & $319 \cdot 4 \pm 32 \cdot 3 * * *$ & $55 \cdot 1 \pm 13 \cdot 5^{* * *}$ & $136 \cdot 1 \pm 4 \cdot 4^{* * *}$ \\
\hline & $\begin{array}{l}\text { Control (sham-op.), } \\
4 \text { weeeks }\end{array}$ & 11 & $82 \cdot 7 \pm 18 \cdot 7$ & $3 \cdot 6 \pm 1 \cdot 3$ & $74.4 \pm 6.4$ \\
\hline \multirow[t]{2}{*}{ IID } & $\begin{array}{l}\text { Ganglionectomized, } \\
8 \text { weeks }\end{array}$ & 8 & $407 \cdot 4 \pm 55 \cdot 8^{* * *}$ & $135 \cdot 6 \pm 35 \cdot 7^{*}$ & $147.9 \pm 7.0^{* * *}$ \\
\hline & $\begin{array}{l}\text { Control (sham-op.), } \\
8 \text { weeks }\end{array}$ & 6 & $98.9 \pm 27.0$ & $26 \cdot 8 \pm 10 \cdot 0$ & $80.7 \pm 5.2$ \\
\hline \multirow[t]{2}{*}{ IIE } & $\begin{array}{l}\text { Ganglionectomized, } \\
4 \text { weeks }\end{array}$ & 13 & $373 \cdot 1 \pm 48 \cdot 8$ & $116 \cdot 3 \pm 13 \cdot 2^{* *}$ & $141.5 \pm 4.9$ \\
\hline & $\begin{array}{l}\text { Control (sham-op.), } \\
4 \text { weeks }\end{array}$ & 13 & $307 \cdot 8 \pm 38 \cdot 3$ & $67 \cdot 5 \pm 10 \cdot 5$ & $131.0 \pm 6.8$ \\
\hline \multirow[t]{2}{*}{ IIF } & $\begin{array}{l}\text { Ganglionectomized, } \\
8 \text { weeks }\end{array}$ & 9 & $370 \cdot 8 \pm 38 \cdot 4^{* *}$ & $158 \cdot 0 \pm 24 \cdot 0^{*}$ & $177.9 \pm 8.4$ \\
\hline & $\begin{array}{l}\text { Control (sham-op.). } \\
8 \text { weeks }\end{array}$ & 10 & $200 \cdot 4 \pm 28 \cdot 4$ & $81 \cdot 2 \pm 15 \cdot 4$ & $151 \cdot 5 \pm 10.4$ \\
\hline
\end{tabular}

Significantly different from respective control group: ${ }^{*} P<0.05 ;{ }^{* *} P<0.01 ;{ }^{* * *} P<0.001$,

These results indicate that the pineal gland is involved in light-induced gonadal changes in Microtus agrestis and that an intact sympathetic nerve supply from the superior cervical ganglion is necessary for this aspect of pineal function.

In these experiments, inhibition by the pineal in immature animals is upon a gonad with minimal development in terms of spermatogenic and androgenic activity. On the other hand the testes of the mature animals contained abundant spermatozoa and active interstitial tissue. It is therefore not surprising that immature and adult animals responded differently and is reminiscent of what appears to happen in the natural state. Worth, Charlton \& MacKinnon (1973) have shown that there are two populations of males in the wild in September consisting of older animals with large testes, seminal vesicles and abundant amounts of pituitary $\mathbf{L H}$ and younger animals with small testes, seminal vesicles and a paucity of LH in the pituitary. The adult animals are presumably less sensitive to an inhibitory stimulus relayed via the pineal, and continue to breed until September, whilst younger animals born late in the year are inhibited and do not reach full spermatogenesis until the following season. Similar results have been found by Lincoln \& MacKinnon (1976) for the hare.

This work was supported by grants from the MRC. Thanks are also given to Mrs S. Lewis and Mr G. Ferrick for technical assistance

\section{References}

Clarke, J.R. \& Farrar, G. (1975) The effect of pinealectomy and chemical sympathectomy upon gonadal function in the vole, Microtus agrestis. Acta endocr., Copenh., Suppl. 199, 248.
Clarke, J.R. \& Kennedy, J.P. (1967) Effect of light and temperature upon gonad activity in the vole (Microtus agrestis). Gen. \& compar. Endocr. 8, 474 488. 
HaAse, E. \& FolletT, B.K. (1974) Effects of pinealectomy on the pituitary gonadal axis of male bramblings (Fringilla montifringilla). Gen. \& compar. Endocr. 22, 386.

Herbert, J. (1971) The role of the pineal gland in the control by light of the reproductive cycle of the ferret. In The Pineal Gland, pp. 303-327. CIBA Fndn. Symp. Eds G.E.W. Wolstenholme \& J. Knight. Churchill Livingstone, London.

HoffMaN, R.A. \& Reiter, R.J. (1965) Pineal gland: influence on gonads of male hamsters. Science, N.Y. 148, 1609-1611.

KAPPERS, J.A. (1965) Survey of the innervation of the epiphysis cerebri and the accessory pineal organs of vertebrates. Progr. Brain. Res. 10, 87-153.
Lincoln, G.A. \& MacKinnon, P.C.B. (1976) A study of seasonally delayed puberty in the male hare, Lepus europaeus. J. Reprod. Fert. 46, 123-128.

Reiter, R.J. (1973) Comparative physiology. Pineal gland. A. Rev. Physiol. 35, 305-328.

REITER, R.J. \& HESTER, R.J. (1966) Interrelationships of the pineal gland, the superior cervical ganglia and the photoperiod in the regulation of the endocrine system of hamsters. Endocrinology 79, 11681170.

Worth, R.W., Charlton, H.M. \& MacKinnon, P.C.B. (1973) Field and laboratory studies on the control of Iuteinizing hormone secretion and gonadal activity in the vole, Microtus agrestis. J. Reprod. Fert., Suppl. 19, 89-99.

Received 9 April 1976 